\title{
49 (1509)
}

\section{Latent infection in experimental spirochaetosis.}

\author{
By JoHN L. TODd.
}

\section{[From McGill University, Montreal.]}

The following observations were made while studying immunity to Spirochata recurrentis in white rats. Since it had been suggested that an immunity might be maintained by persistent latent infection, it was necessary to make careful examinations for spirochætes in all animals exhibiting resistance to infection.

The work was done with strains of spirochætes which usually produced well-marked infection with one or more relapses. During the observation of several hundred animals it was noticed that parasites occasionally reappeared in the peripheral circulation after unusually long absences. It often happened that spirochætes were found in blood films, on one or two days, after they had been absent for from ten to fifteen days; once spirochætes were seen after an absence of twenty-one days. Blood, taken from the tail, was examined for spirochætes in thick dehemoglobinized and stained films. Examinations, throughout the work, were made daily.

It of ten happens that a normal infection follows when a rat is inoculated with blood from an animal, once infected, although repeated examinations have failed to find spirochætes in it. In many instances, infection resulted when rats were inoculated with blood taken from other rats which were killed from fifteen to twenty days, in one instance twenty-seven days, after spirochætes were last found in them by microscopical examination.

Although the inoculation of blood, and other material, obtained by killing an experimental animal, is sometimes a more efficient method of detecting spirochætal infection, it is not always so and, since it involves the destruction of the animal supplying the material inoculated, it is a method which cannot be repeated. Inoculation of material in which living spirochætes have been seen occasionally fails to infect one of two rats inoculated at the 
same time; sometimes, also, the infection produced remains unseen by microscopical examination and is only detected by killing the inoculated animal and by sub-inoculating another rat with blood from it. Inoculations are less likely to fail, or result in unobvious infection when considerable quantities of blood are inoculated.

In order to obtain considerable quantities of material for inoculation from rats in which spirochætes could not be found by blood examinations, blood was aspirated from hearts and spleens were excised. Of these two methods the aspiration of heart's blood was the more successful. Under chloroform, it is easy to aspirate from I to $2.5 \mathrm{ccm}$. of blood from the heart of an adult rat without injuring the animal. By so doing, spirochaetes were shown, in one instance, to be present in an apparently immune rat thirty-two days after the parasites were last seen by the daily examination of blood films. Previously, this rat had twice been infected by inoculation and had acquired an immunity shown by two unsuccessful inoculations. Two subsequent, also unsuccessful, inoculations showed that the rat was still immune to the strain employed in this experiment. -

It should be remarked that several similar experiments did not reveal latent infections in immune rats.

50 (1510)

The influence of water-soluble vitamine on the nutrition of dogs. By W. G. KARR (by invitation)

[From the Sheffield Laboratory of Physiological Chemistry, Yale University, New Haven, Ct.]

Studies on a few species of animals have indicated that the water-soluble vitamine is of importance to nutrition during all stages of life and that prolonged absence of it from the diet will lead to a diseased condition. In the present investigation the role of water-soluble vitamines in the nutrition of the dog has been under consideration.

The animals were fed a diet devoid of water-soluble vitamine and consisting of lard, sucrose, inorganic salts, and protein in the 